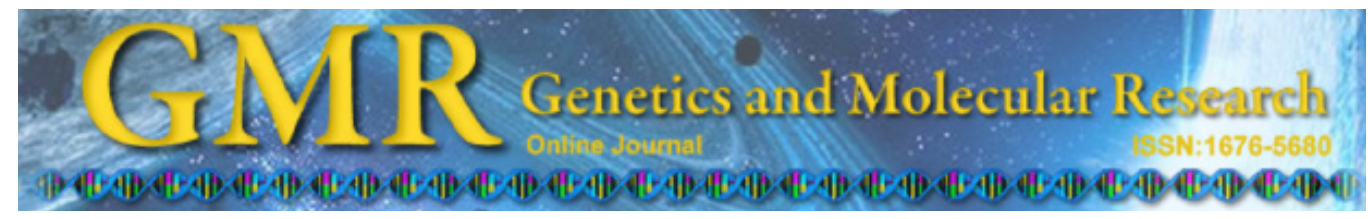

\title{
Detection of differentially expressed genes in the longissimus dorsi of Northeastern Indigenous and Large White pigs
}

\author{
Y. Gao ${ }^{1 *}$, Y.H. Zhang ${ }^{2 *}$, H. Jiang ${ }^{1}$, S.Q. Xiao ${ }^{3}$, S. Wang ${ }^{1}$, Q. Ma ${ }^{2}$, \\ G.J. Sun ${ }^{1}$, F.J. Li ${ }^{1}$, Q. Deng ${ }^{1}$, L.S. Dai ${ }^{1}$, Z.H. Zhao ${ }^{2}$, X.S. Cui ${ }^{1}$, \\ S.M. Zhang ${ }^{4}$, D.F. Liu ${ }^{1}$ and J.B. Zhang ${ }^{1}$ \\ ${ }^{1}$ Laboratory Animal Center, Jilin University, Changchun, Jilin, China \\ ${ }^{2}$ College of Animal Science and Veterinary Medicine, Jilin University, \\ Changchun, Jilin, China \\ ${ }^{3}$ School of Life Science, Sun Yat-sen University, Guangzhou, \\ Guangdong, China \\ ${ }^{4}$ Branch of Animal Husbandry, Jilin Academy of Agricultural Science, \\ Gongzhuling, Jilin, China \\ *These authors contributed equally to this study. \\ Corresponding author: J.B. Zhang \\ E-mail: zjb515@163.com
}

Genet. Mol. Res. 10 (2): 779-791 (2011)

Received November 22, 2010

Accepted January 13, 2011

Published May 3, 2011

DOI 10.4238/vol10-2gmr1170

\begin{abstract}
Recent attention in pig breeding programs has focused on the improvement of pork quality in response to increasing consumer demands. Compared to the fatty-type Northeastern Indigenous (Chinese) breed of pigs, the lean-type Large White has lower intramuscular fat and inferior eating quality from the perspective of the Chinese consumer. In order to investigate the molecular basis of differences in pork quality in Chinese indigenous and Western breeds, longissimus dorsi samples were collected from three adult Northeastern Indigenous and three adult Large White pigs. The RNAs were extracted and hybridized to the porcine Affymetrix GeneChip. Microarray analysis demonstrated differential expression of 1134 genes of which 401 have a known
\end{abstract}


function. One hundred and thirty-six genes were up-regulated and 998 down-regulated in Northeastern Indigenous breed compared to Large White pigs. We screened 10 genes as candidate genes associated with pork quality. We investigated a single nucleotide polymorphism in the 5 ' regulatory region of the gene FABP4 in 65 Songliao black swine, using PCR-single-strand conformational polymorphism. We found this polymorphism to be highly significantly associated with marbling and intra-muscular fat content $(\mathrm{P} \leq 0.01)$. Genotype $\mathrm{BB}$ had higher marbling than $\mathrm{AB}$ and $\mathrm{AA}$, but there was no significant difference between $\mathrm{AB}$ and $\mathrm{AA}$. Genotype $\mathrm{BB}$ and $\mathrm{AB}$ had higher intra-muscular fat content than $\mathrm{AA}$, but there was no significant difference between $\mathrm{BB}$ and $A B$. These results help to elucidate the genetic mechanisms behind differences in pork quality and provide a theoretical basis for selection and genetic improvement of meat quality traits in pigs.

Key words: Adipocyte fatty acid-binding protein; Gene expression; Longissimus dorsi; Meat quality; Pigs; Polymorphism

\section{INTRODUCTION}

In recent decades, meat quality traits have received increased attention by pig breeders, since selection for high growth rate and lean meat deposition has resulted in a reduction in meat eating quality. It is therefore important to understand the genetic and biological mechanisms that may be exploited and lead to new selection strategies appropriate for meat quality traits. High-throughput screening of differentially expressed genes is required in order to study the regulatory mechanisms behind meat quality traits. Gene chip technique has an important role in analyzing alterations in gene expression across the whole genome (Zhao et al., 2005).

The Northeastern Indigenous and Large White breeds show obvious differences in meat quality traits. Pork of the former is of substantial quality with well-distributed marbling and bright-red coloration, and the meat is tender and juicy. By comparison, the pork of the Large White is poor in quality, has a grayish-white color, and is less appealing to the palate. Previous studies have indicated that characteristics of longissimus dorsi play a key role in determining meat quality (Picard et al., 2002; Hamilton et al., 2003). Therefore, the present study investigated differences in the expression profiles of genes in the longissimus dorsi of Northeastern Indigenous and Large White pigs by use of high-throughput microarray.

The objective of the present investigation was to utilize the GeneChip Porcine Genome Array from Affymetrix to identify differentially expressed genes associated with meat quality in the pig. Identification and characterization of gene expression patterns in different pig breeds will provide a better understanding of the processes required to improve pork quality.

\section{MATERIAL AND METHODS}

\section{Tissue samples}

All animal procedures were performed according to the Animal Protection Law of the People's Republic of China. Three Northeastern Indigenous and three Large White used in the 
study were obtained from the Branch of Animal Husbandry at Jilin Academy of Agricultural Science. They were bucks and bred under identical conditions. They were butchered on day 150. Longissimus dorsi samples were collected and washed briefly with PBS before being snap frozen in liquid nitrogen for future use.

Liver tissues of 65 Songliao black swine were collected from the same place; rearing and feeding conditions were equalized. The samples were stored at $-20^{\circ} \mathrm{C}$ after immersion in $75 \%$ ethanol.

\section{Measurement of meat quality traits}

The methods used to assess meat quality were those adopted by the Branch of Animal Husbandry at Jilin Academy of Agricultural Science and are shown in Table 1. All results are reported as means \pm SD. Statistical analysis was performed by one-way ANOVA using SPSS 13.0.

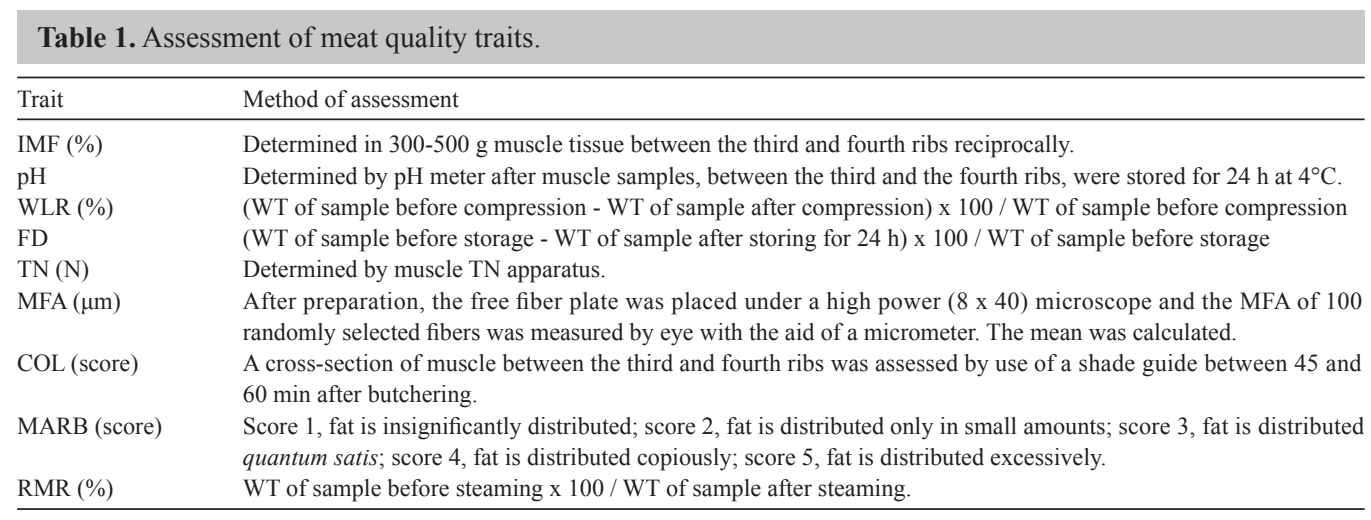

$\mathrm{IMF}=$ intramuscular fat content; $\mathrm{pH}=24-\mathrm{h} \mathrm{pH}$ values; $\mathrm{WLR}=$ water loss rate; $\mathrm{FD}=$ fail drip; $\mathrm{TN}=$ tenderness; $\mathrm{MFA}=$ muscle fiber diameter; $\mathrm{COL}=$ coloration; $\mathrm{MARB}=$ marbling; $\mathrm{RMR}=$ ripe muscle rate; $\mathrm{WT}=$ weight.

\section{RNA extraction}

Total RNA of Northeastern Indigenous and Large White was isolated from approximately $200 \mathrm{mg}$ frozen tissue using Trizol reagent (Invitrogen, Auckland, New Zealand) according to manufacturer instructions. The RNA concentration and purity were determined spectrophotometrically and checked by electrophoresis through $1 \%$ agarose gels. Each RNA sample was used for one slide hybridization.

\section{Array hybridization}

Gene expression profiling was performed for each RNA sample separately on the GeneChip $^{\circledR}$ Porcine Genome Array from CapitalBio Corporation (Beijing, China), a service provider authorized by Affymetrix Inc. (Santa Clara, CA, USA). Microarray procedures were performed according to the GeneChip ${ }^{\circledR}$ Expression Analysis Technical Manual (Affymetrix, Rev. 5, Part No. 701021). In brief, $1 \mu \mathrm{g}$ total RNA was reverse transcribed to first- and secondstrand cDNAs. After purification and testing, the double-stranded cDNA served as a template for the in vitro transcription reaction required for cRNA amplification. cRNA was labeled with biotin and subsequently fragmented and hybridized to the array for $16 \mathrm{~h}$ at $45^{\circ} \mathrm{C}$ with rotation. 
After hybridization, the GeneChip arrays were washed, and then stained with streptavidinphycoerythrin on an Affymetrix Fluidics Station 450, followed by scanning with the Affymetrix GeneChip Scanner 3000 and conversion into TIFF images in preparation for analysis.

\section{Data analysis}

Array normalization and error detection analysis were carried out using the Affymetrix GeneChip Operating Software Version 1.4 (Affymetrix). Data were normalized by the algorithms supplied with the feature extraction software. After normalization, one final qualitycontrol filter was applied, where genes showing excessive biological variability were discarded. To identify significantly differentially expressed genes, significance analysis of the microarray results (SAM, version 3.02) was performed. A minimum of a 2 -fold change and $\mathrm{q}$ value $(\%)$ of $\leq 5 \%$ in gene expression were considered to be statistically significant.

\section{Quantitative reverse transcription polymerase chain reaction (qRT-PCR)}

qRT-PCR analysis for 8 representative genes was performed in order to confirm the microarray results. Total RNA was extracted using Trizol reagent, and reverse transcription reactions were performed using the BioRT cDNA First-Strand Synthesis kit (Bioer, Hangzhou, China) following manufacturer instructions. Gene expression in the longissimus dorsi was quantified using the RealMasterMix (SYBR Green I) (Tiangen Biotech, Beijing, China) on a Mastercycler ${ }^{\circledR}$ ep realplex (Jilin University, Jilin, China). The primer pairs used for RT-PCR and the predicted amplicon sizes are listed in Table 2. The PCR system $(20 \mu \mathrm{L})$ contained 9 $\mu \mathrm{L}$ RealMasterMix, $0.3 \mu \mathrm{L}$ of each primer (both $10 \mathrm{mM}$ ), and $1 \mu \mathrm{L}$ of the cDNA template. RT-PCR conditions were as follows: $95^{\circ} \mathrm{C}$ for 2 min followed by 40 cycles of $95^{\circ} \mathrm{C}$ for $15 \mathrm{~s}$, $60^{\circ} \mathrm{C}$ for $20 \mathrm{~s}$ and $68^{\circ} \mathrm{C}$ for $50 \mathrm{~s}$. The specificity of the RT-PCR amplification was confirmed

\begin{tabular}{|c|c|c|c|}
\hline Gene & Accession No. & Sequence (forward / reverse) & Length (bp) \\
\hline$\beta$-actin & DQ452569.1 & $\begin{array}{l}\text { F: GCTCTTCCAGCCCTCCTTCCT } \\
\text { R: TAGAGGTCCTTGCGGATGTCG }\end{array}$ & 200 \\
\hline CYP3A29 & NM_214423.1 & $\begin{array}{l}\text { F: AAAGAATCCGAACATTGCTG } \\
\text { R: ATCACGTCCATGCTGTAGGC }\end{array}$ & 172 \\
\hline CPT1B & NM_001007191.1 & $\begin{array}{l}\text { F: CAAGTCCTTCACCCTCATCGC } \\
\text { R: GGTTTGGTTTGCCCAGACAG }\end{array}$ & 167 \\
\hline FABP4 & NM_001002817.1 & $\begin{array}{l}\text { F: CTTTTTCTTTTCCCAACTG } \\
\text { R: GCAACAGTCTTTTAGGAACCA }\end{array}$ & 250 \\
\hline ACL & NM_001105302.1 & $\begin{array}{l}\text { F: GAGGCAGCATCGCAAACTTCAC } \\
\text { R: GGTCTTCCCAACTTCTCCCATC }\end{array}$ & 170 \\
\hline COFILIN & NM_001004043.1 & $\begin{array}{l}\text { F: GGACCTGGTGTTCATCTTCTGG } \\
\text { R: CCTCGTAGCAGTTCGCTTGTAAT }\end{array}$ & 134 \\
\hline MGST1 & NM_214300.1 & $\begin{array}{l}\text { F: CGGACAGATGAAAGAGTGGAACG } \\
\text { R: AAAGAGTCTGAAGTGCAGGATGG }\end{array}$ & 141 \\
\hline ITG $\beta 2$ & NM_213908.1 & $\begin{array}{l}\text { F: ATCGGCTTTGGGTCTTTCGTG } \\
\text { R: TGGTTGGAGTTGTCCGTGAGC }\end{array}$ & 152 \\
\hline SCD & NM_213781.1 & $\begin{array}{l}\text { F: CCGCCCTGAAATGAAAGATGAC } \\
\text { R: GTAGGCAAACGCCCAGAGCAAG }\end{array}$ & 184 \\
\hline
\end{tabular}

$\beta$-actin = beta actin; CYP3A29 = cytochrome P450 3A29; CPT1B = carnitine palmitoyl transferase 1B; FABP4 = adipocyte fatty acid binding protein; $\mathrm{ACL}=\mathrm{ATP}$ citrate lyase; $\mathrm{COFILIN}=\mathrm{COFILIN}$ protein; $\mathrm{MGST} 1=$ microsomal glutathione S-transferase 1; ITG $\beta 2$ = integrin beta 2; SCD = stearoyl-CoA desaturase. 
by dissociation curve analysis. The results were standardized to control values of Sus scrofa $\beta$-actin. In this study, a relative quantification assay was performed for target gene mRNA by applying the $2^{-\Delta \Delta \mathrm{Ct}}$ method as described elsewhere (Pfaffl, 2001; Tichopad et al., 2003). All experiments were performed in triplicate.

\section{DNA extraction and primer design}

Genomic DNA of Songliao black swine was extracted according to a protocol described elsewhere (Sambrook et al., 1989) and detected using 0.8\% agarose gel electrophoresis. The primers were designed according to the GenBank FABP4 sequence (accession No. Y16039). The upstream primer was 5'-GGGAAGATTTCAGGATACT-3' and the downstream primer was 5'-AATCAGAAGTGGTTTGGTCAC-3'. The primers were synthesized by Shanghai Sangon Biological Engineering Technology \& Services Co. Ltd.

\section{PCR amplification}

The PCR mixture contained $50 \mathrm{ng}$ DNA template, $10 \mathrm{mM}$ of each primer, $2.5 \mathrm{mM}$ dNTP mixture, $10 \mathrm{X}$ buffer (including $1.5 \mathrm{mM} \mathrm{MgCl}_{2}$ ) and $1 \mathrm{U}$ Taq DNA polymerase in a $50-\mu \mathrm{L}$ reaction volume. Amplification conditions were as follows: denaturation at $94^{\circ} \mathrm{C}$ for 5 min, 32 cycles of amplification at $94^{\circ} \mathrm{C}$ for $30 \mathrm{~s}, 59^{\circ} \mathrm{C}$ for $1 \mathrm{~min}$, and $72^{\circ} \mathrm{C}$ for $1 \mathrm{~min}$, and a final extension step at $72^{\circ} \mathrm{C}$ for $10 \mathrm{~min}$. The amplification products were detected using $1.5 \%$ agarose gel electrophoresis and visualized using a UV transilluminator.

\section{Genetic variation identification and sequencing}

The PCR products from 65 pigs were genotyped using $12 \%$ native polyacrylamide gel electrophoresis (PAGE) $(150 \mathrm{~V}, 16 \mathrm{~h})$. The PCR product $(2 \mu \mathrm{L})$ was mixed with $5 \mu \mathrm{L}$ of the loading buffer. PCR products were denatured for $10 \mathrm{~min}$ at $98^{\circ} \mathrm{C}$, and the mixture was immediately cooled on ice for $10 \mathrm{~min}$. The denatured samples were loaded onto a $12 \%$ polyacrylamide gel using a micro-injector. After electrophoresis, the gel was shaken lightly for 10-15 min in 70\% ethanol and for 20 min in staining solution after washing with $\mathrm{ddH}_{2} \mathrm{O}$. Washing was repeated three times after incubation in the staining solution. The staining solution was added until bands appeared clearly. The reaction was terminated by washing the gel. A refrigerated circulator was used to control the temperature $\left(4^{\circ} \mathrm{C}\right)$ of the gels.

PCR products showing homozygous genotypes were cloned and sequenced by Shanghai Sangon Biological Engineering Technology \& Services Co. Ltd. The DNAMAN software package was used to confirm the FABP4 DNA sequence and to detect the polymorphic locus.

\section{Statistical analysis}

The chi-squared test of the allele frequencies for Songliao black swine was performed. Associations between genotypes and meat quality traits were analyzed using the general linear model procedure of SPSS version 13.0. The linear model is:

$$
Y_{i j k}=\mu+A_{i}+G_{j}+S_{k}+E_{i j k}, \quad \text { (Equation 1) }
$$


where $Y_{i j k}$ is the observation for meat quality trait, $\mu$ is the overall population mean, $A_{i}$ is the fixed effect of the $\mathrm{i}^{\text {th }}$ age, $G_{j}$ is the fixed effect of $\mathrm{j}^{\text {th }}$ genotype (AA, AB and BB genotypes), $S_{k}$ is the fixed effect of sex, and $E_{i j k}$ is the random error. Significance of difference was tested using Duncan's multiple comparison.

\section{RESULTS}

\section{Comparison of meat quality traits between Northeastern Indigenous and Large White}

Significant differences between the two breeds of pig were observed in a number of meat quality traits, including intramuscular fat content, marbling, tenderness, coloration, and ripe muscle rate (Table 3). It was evident from the data that meat from Northeastern Indigenous pigs was of superior quality to that of Large White animals.

Table 3. Meat quality traits of the two pig breeds.

\begin{tabular}{lcrl}
\hline Trait & \multicolumn{2}{c}{ Pig breed } & P \\
\cline { 2 - 4 } & Northeastern Indigenous & Large White & 0.000 \\
\hline IMF (\%) & $4.08 \pm 0.25^{\mathrm{a}}$ & $1.75 \pm 0.19^{\mathrm{b}}$ & 0.148 \\
pH & $5.82 \pm 0.15$ & $5.69 \pm 0.13$ & 0.742 \\
WLR (\%) & $14.77 \pm 1.43$ & $15.08 \pm 1.77$ & 0.776 \\
FD & $3.05 \pm 0.42$ & $3.16 \pm 0.78$ & 0.005 \\
TN (N) & $2.07 \pm 0.18^{\mathrm{a}}$ & $2.49 \pm 0.22^{\mathrm{b}}$ & 0.207 \\
MFA ( $\mu$ m) & $48.73 \pm 0.51$ & $49.06 \pm 0.32$ & 0.004 \\
COL (score) & $2.83 \pm 0.18^{\mathrm{a}}$ & $2.47 \pm 0.16^{\mathrm{b}}$ & 0.000 \\
MARB (score) & $3.12 \pm 0.8^{\mathrm{a}}$ & $1.58 \pm 0.49^{\mathrm{b}}$ & 0.045 \\
RMR (\%) & $57.21 \pm 1.00^{\mathrm{a}}$ & $60.42 \pm 3.28^{\mathrm{b}}$ & \\
\hline
\end{tabular}

Values are reported as means $\pm \mathrm{SD}$ for $\mathrm{N}=6$. In the same row, means without a common superscript letter differ $(\mathrm{P}<0.05) . \mathrm{IMF}=$ intramuscular fat content; $\mathrm{pH}=24-\mathrm{h} \mathrm{pH}$ values; $\mathrm{WLR}=$ water loss rate; $\mathrm{FD}=$ fail drip; $\mathrm{TN}=$ tenderness; $\mathrm{MFA}=$ muscle fiber diameter; $\mathrm{COL}=$ coloration; $\mathrm{MARB}=$ marbling; $\mathrm{RMR}=$ ripe muscle rate.

\section{Differentially expressed genes in the longissimus dorsi of the two breeds}

Longissimus dorsi gene expression profiles of the two breeds were obtained using the Affymetrix Porcine Genome Array. A total of 24,123 probe sets were utilized to comprehensively screen the porcine transcriptome (GEO accession Nos. GSM595112-GSM595117). A total of 1134 genes were regarded as being differentially expressed: 136 of the genes were up-regulated, while 998 were down-regulated in Northeastern Indigenous animals. Annotation of the differentially expressed genes was performed via the NetAffxAnalysis Center (http://www.affymetrix. com/analysis/index.affx). This analysis found that 401 of the genes had a known function, while the function was unknown for the remaining 733 genes. Genes involved in fatty acid metabolism and regulation of actin were screened via the keyword method; they are presented in Table 4.

\section{Real-time PCR}

Eight genes (CYP3A29, CPT1B, FABP4, ACL, COFILIN, MGST1, ITGß2, SCD) were selected to validate the microarray data by the use of real-time PCR. The results indicated that the expression patterns of these genes were consistent with the microarray data (Figure 1). 
Table 4. List of differentially expressed genes associated with meat quality.

\begin{tabular}{llll}
\hline Probe set ID & Gene name (Gene symbol) & RefSeq Transcript ID & Fold change \\
\hline Ssc.204.1.S1_at & cytochrome P450 3A29 (CYP3A29) & NM_214423 \\
Ssc.15966.1.S1_at & carnitine palmitoyl transferase 1B (CPT1B) & NM_001007191 \\
Ssc.16159.1.S1_at & stearoyl-CoA desaturase (SCD) & NM_213781 \\
SscAffx.22.1.S1_s_at & COFILIN protein (COFILIN) & NM_001004043 \\
Ssc.1089.1.S1_at & fatty acid-binding protein 4, adipocyte (FABP4) & NM_001002817 \\
Ssc.14561.1.S1_at & integrin beta 2 (ITGß2) & NM_213908 \\
Ssc.1013.1.A1_at & microsomal glutathione S-transferase 1 (MGST1) & NM_214300 \\
Ssc.30707.1.S1_at & ATP citrate lyase (ACL) & NM_001105302 & -2.33 \\
Ssc.18175.1.A1_at & fatty acid synthase (FASN) & NM_001099930 & -3.60 \\
Ssc.18549.1.S1_at & adiponectin, C1Q and collagen domain containing (ADIPOQ) & NM_214370 & -18.03 \\
\hline
\end{tabular}

Probe set identification from Affymetrix Porcine GeneChip (Affymetrix, Santa Clara, CA, USA). Accession No. in the National Center for Biotechnology Information database. Fold change $=$ Northeastern Indigenous pig/Large White pig; a minimum of a 2-fold change in gene expression was considered to be statistically significant based on significance analysis of the microarray results (SAM, version 3.02).

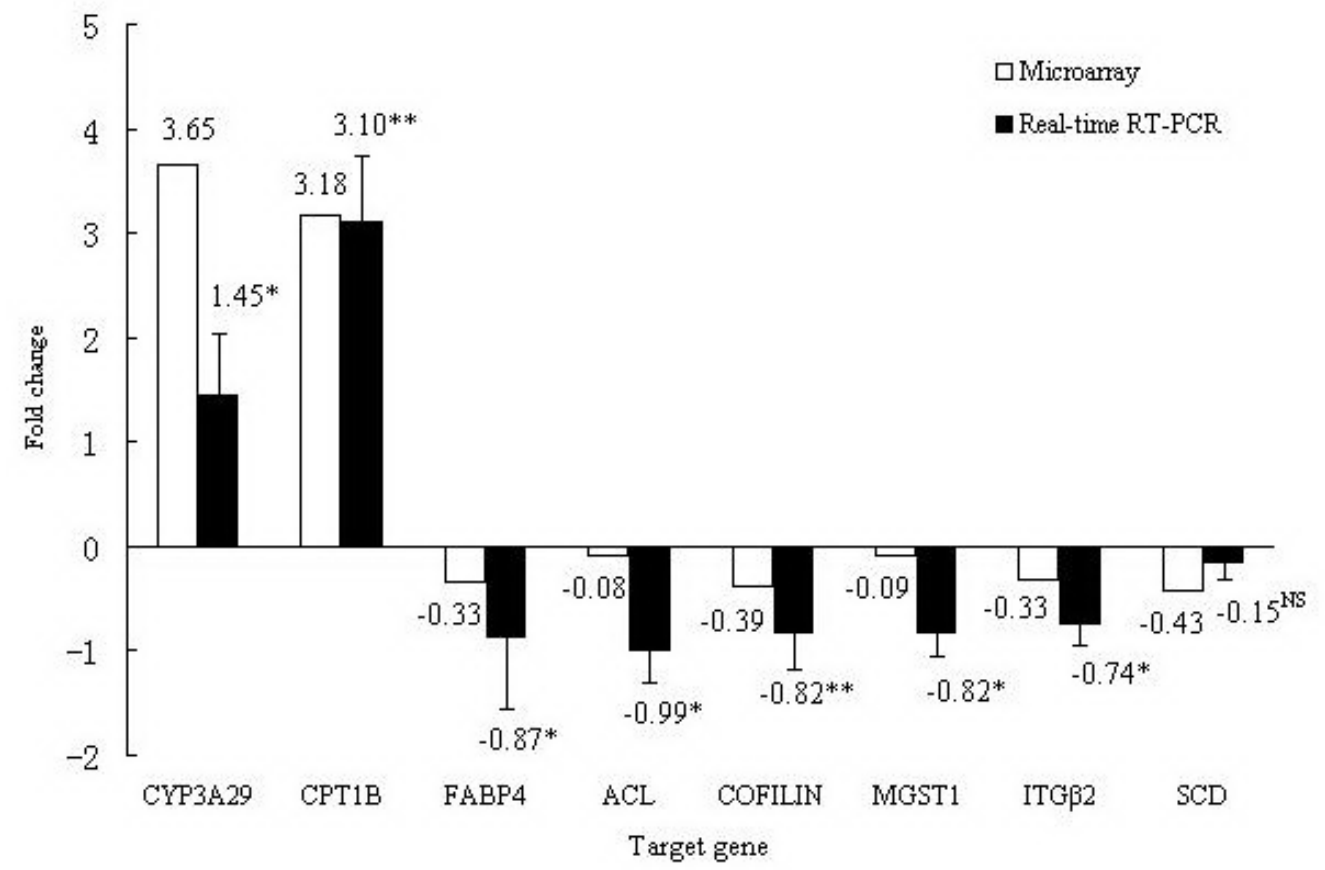

Figure 1. Validation of the microarray data by RT-PCR analysis of eight representative genes. Expression levels of eight genes were quantified by RT-PCR and microarray. All fold changes from the microarray analysis are statistically significant $(\mathrm{P}<0.01)$. Statistical significance of fold changes estimated through RT-PCR analysis is indicated as NS $=$ not significant $(\mathrm{P}>0.05) ; * \mathrm{P}<0.05 ; * * \mathrm{P}<0.01$. Target genes: CYP3A29 = cytochrome $\mathrm{P} 450$ $3 \mathrm{~A} 29$; CPT1B = carnitine palmitoyl transferase $1 \mathrm{~B} ; \mathrm{FABP} 4=$ adipocyte fatty acid-binding protein; ACL $=$ ATP citrate lyase; COFILIN = COFILIN protein; MGST1 = microsomal glutathione S-transferase 1; ITG $\beta 2=$ integrin beta $2 ; \mathrm{SCD}=$ stearoyl-CoA desaturase. 


\section{Single-strand conformational polymorphism (SSCP)}

PCR products at the 5' regulatory region of the Songliao black swine FABP4 gene were detected using $12 \%$ native polyacrylamide gel electrophoresis. Three different genotypes designated $\mathrm{AA}, \mathrm{AB}$ and $\mathrm{BB}$ were identified in the pig population using SSCP (Figure 2A).

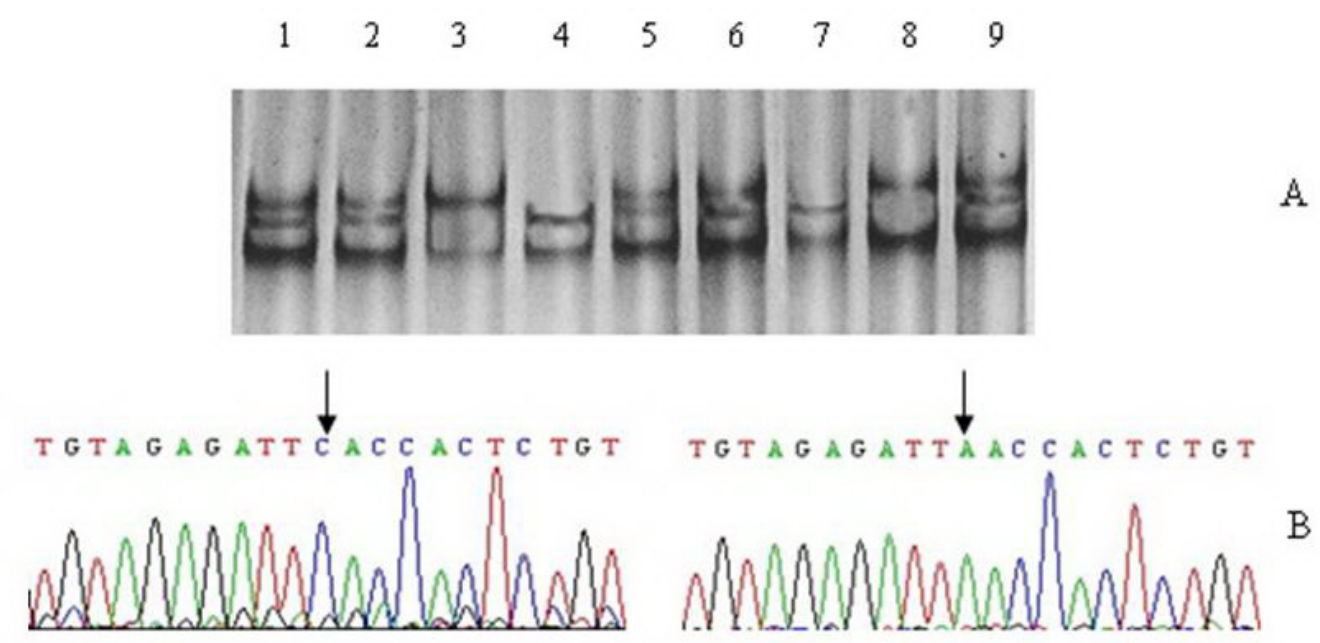

Figure 2. A. Electrophoresis patterns of PCR-SSCP in the 5' regulatory region of Songliao black swine FABP4 gene. Lanes 1, 2, 5, 6, 9= AB genotype; lanes 3, 8=AA genotype; lanes 4, $7=\mathrm{BB}$ genotype. $\mathrm{B}$. Chromatograms showing mutation in the 5 ' regulatory region of Songliao black swine FABP4 gene.

\section{Gene and genotypic frequency}

The genotypic frequency of AB for FABP4 was the highest in Songliao black swine (Table 5), and the genotypic frequency of BB was higher than that of AA. The frequency of alleles A and B were 0.42 and 0.58 , respectively. Songliao black swine did not achieve a level of significance using the $\chi^{2}$ test, i.e., gene and genotypic frequency were in Hardy-Weinberg equilibrium $\left(\chi^{2}=2.64, \mathrm{P}>0.05\right)$.

Table 5. Gene and genotypic frequency of FABP4 in Songliao black swine.

\begin{tabular}{|c|c|c|c|c|c|c|}
\hline \multirow[t]{2}{*}{$\mathrm{N}$} & \multicolumn{2}{|c|}{ Gene frequency } & \multicolumn{3}{|c|}{ Genotypic frequency (n) } & \multirow[t]{2}{*}{$\chi^{2}(\mathrm{HWE})$} \\
\hline & A & $\mathrm{B}$ & AA & $\mathrm{AB}$ & BB & \\
\hline 65 & 0.42 & 0.58 & $0.12(8)$ & $0.58(38)$ & $0.29(19)$ & 2.64 \\
\hline
\end{tabular}

$\mathrm{N}=$ number of experimental pig populations; $\mathrm{n}=$ number of observations; $\chi^{2}(\mathrm{HWE})=$ Hardy-Weinberg equilibrium by the $\chi^{2}$ test; d.f. $=2, \chi_{0.05}^{2}=5.99$ (P value was above 0.05$)$. 


\section{Sequencing}

PCR fragments representing homozygous genotypes were sequenced to reveal mutations of $\mathrm{C} \rightarrow \mathrm{A}$ at position $1321 \mathrm{bp}$ in the 5 ' regulatory region of the FABP4 genomic sequence (GenBank accession No. Y16039). Sequencing figures of the two homozygous genotypes are presented in (Figure 2B).

\section{Association between different FABP4 genotypes and meat quality traits}

Statistical analysis demonstrated a significant association between single nucleotide polymorphism (SNP) and marbling, and SNP and intramuscular fat (IMF) content, but no significant association between SNP and other traits in Songliao black swine (Table 6). Marbling of the genotype $\mathrm{BB}$ was significantly higher than that of genotypes $\mathrm{AA}$ and $\mathrm{AB}$, respectively $(\mathrm{P}<0.05)$; there was no significant difference between the $\mathrm{AA}$ and $\mathrm{AB}$ genotypes $(\mathrm{P}>0.05)$. The IMF content of genotypes $\mathrm{BB}$ and $\mathrm{AB}$ was significantly higher than that of genotype $\mathrm{AA}$ $(\mathrm{P}<0.01)$ : there was no significant difference between the $\mathrm{BB}$ and $\mathrm{AB}$ genotypes $(\mathrm{P}>0.05)$.

Table 6. Association of FABP4 gene polymorphism with meat quality traits in Songliao black swine.

\begin{tabular}{lrrrr}
\hline \multirow{2}{*}{ Trait } & \multicolumn{2}{c}{ Genotypes } & F value & P \\
\cline { 2 - 4 } & \multicolumn{1}{c}{ AA } & \multicolumn{1}{c}{ AB } & \multicolumn{1}{c}{ BB } & \\
\hline COL (score) & $3.01 \pm 0.15$ & $3.27 \pm 0.10$ & $3.20 \pm 0.10$ & 0.35 \\
pH & $5.50 \pm 0.08$ & $5.62 \pm 0.02$ & $5.99 \pm 0.03$ & 0.10 \\
RMR (\%) & $60.89 \pm 1.77$ & $61.58 \pm 0.81$ & $63.08 \pm 1.27$ & 2.46 \\
FD & $2.20 \pm 0.05$ & $2.21 \pm 0.04$ & $2.22 \pm 0.03$ & 1.84 \\
WLR (\%) & $35.55 \pm 0.68$ & $35.22 \pm 0.37$ & $36.88 \pm 0.53$ & 8.65 \\
MFA ( $\mu$ m) & $41.38 \pm 1.05$ & $40.91 \pm 0.49$ & $41.10 \pm 0.74$ & 0.65 \\
MARB (score) & $2.28^{\mathrm{a}} \pm 0.12$ & $2.36^{\mathrm{a}} \pm 0.14$ & 0.21 & 0.12 \\
TN (N) & $2.21 \pm 1.71$ & $2.09 \pm 0.56$ & $2.84^{\mathrm{b}} \pm 0.20$ & 0.80 \\
IMF (\%) & $2.27^{\mathrm{a}} \pm 0.06$ & $2.68^{\mathrm{b}} \pm 0.02$ & $2.16 \pm 1.19$ & 0.13 \\
\hline
\end{tabular}

Data are reported as least square means \pm standand error $(\mathrm{LSM} \pm \mathrm{SE}) . \mathrm{COL}=$ coloration; $\mathrm{pH}=24-\mathrm{h} \mathrm{pH}$ values; $\mathrm{RMR}=$ ripe muscle rate; $\mathrm{FD}=$ fail drip; $\mathrm{WLR}=$ water loss rate; $\mathrm{MFA}=$ muscle fiber diameter; $\mathrm{MARB}=$ marbling; $\mathrm{TN}=$ tenderness; IMF = intramuscular fat content. LSMs with different superscript letters in the same row differ $(\mathrm{P}<0.05)$.

\section{DISCUSSION}

\section{Genes involved in fatty acid metabolism and the adipocytokine signaling pathway}

Adiponectin, C1Q and collagen domain containing (ADIPOQ) is a kind of collagen cytokine secreted by adipose tissue, which is involved in the control of fat metabolism and insulin sensitivity. The ADIPOQ gene is located in the pig genome at 13q41 (Nowacka-Woszuk et al., 2008). ADIPOQ acts as an autocrine/paracrine factor in vivo, and may participate in the regulation of both adipocyte metabolism and adipose tissue mass (Fu et al., 2005). A previous study has suggested that ADIPOQ is the most abundant protein secreted by white adipose tissue, and that its secretion is negatively correlated with the mass of adipose tissue (Kadowaki and Yamauchi, 2005; Kadowaki et al., 2007). The present study found that the ADIPOQ gene 
was significantly associated with fatty acid oxidation, positive regulation of fatty acid metabolism and fatty acid $\beta$-oxidation. Moreover, the ADIPOQ gene produced a marked effect on the adipocytokine signaling pathway. It is thus clear that the ADIPOQ gene is associated with fat metabolism and could be used for studying the genetic mechanisms determining meat quality traits.

The human carnitine palmitoyl transferase 1B (CPT1B) gene is known to contain two alternatively transcribed first exons (van der Leij et al., 1997), whereby either exon 1A (Yamazaki et al., 1997), also called U (Yu et al., 1998), or exon 1B, also called M, is transcribed. In the rat, only a single first exon has been found (Wang et al., 1998; van der Leij et al., 2002), which is equivalent to human exon 1B (M). The human CPT1B gene maps to the telomeric region of the long arm of chromosome 22 (Britton et al., 1997) while the mouse CPT1B gene has been mapped to chromosome 15. Human CPT1B initiates mitochondrial import in the degradation of fatty acids through mitochondrial $\beta$-oxidation (Brouns and van der Vusse, 1998). The ovine CPT1B transcript has been found to be abundant in heart, muscle and lactating mammary gland tissue (Price et al., 2003). In the present study, the pig CPT1B gene significantly influenced long-chain fatty acid transport, fatty acid metabolism and lipid metabolism. In addition, the CPT1B gene was involved in both fatty acid metabolism and the adipocytokine signaling pathway. To date, research on the CPT1B gene has focused on humans, rats and sheep, and few reports document its role in pigs. The CPT1B gene may act as a candidate gene via which meat quality traits may be further studied.

\section{Candidate genes for fat metabolism}

Fat traits influence mammalian meat quality but the regulation of mammalian body fat is a complicated process whereby the level of fat is affected by variables such as breed and age. Fatty acid synthase (FASN) is regarded as an essential metabolic enzyme and plays an important role in determining the form and deposition of mammalian body fat. Cloning and sequencing of the FASN gene have been performed in many mammals, including rats (M84761), mice (X13135, AF127033), humans (NM-004104) and pigs (AY183428), and in fowl (J04485). The FASN gene is located in the human genome at $17 \mathrm{q} 25$ and in the fowl genome at 18q. In the pig genome it has been located at $12 \mathrm{p} 1.5$ using physical mapping and linkage analysis (Muñoz et al., 2003), while in the ovine genome it has been located at 19q22 using in situ hybridization and somatic hybridization (Roy et al., 2001). FASN plays a central role in lipogenesis through the synthesis of saturated long-chain fatty acids from acetyl-CoA and malonyl-CoA. It is implicated in lipogenesis of fatty acids taken up from plasma and from those synthesized de novo (Yang et al., 2003). Through its key function in lipogenesis, FASN may play a crucial role in determining the variability in weight of abdominal adipose tissue. Moreover, it has been found to be involved in lipid metabolism pathways in studies of pre- and postnatal hepatic gene expression profiles of two pig breeds differing in body composition (Ponsuksili et al., 2007). The present study found that FASN regulates fatty acid biosynthesis, lipid biosynthesis and fatty acid synthase activity. The association of FASN gene polymorphisms with production traits had been studied in pigs, chickens (Douaire et al., 1992; Sourdioux et al., 1999; Roy et al., 2006) and sheep (Morris et al., 2007). These studies suggest that FASN is a candidate gene influencing fat traits, a conclusion which is consistent with the results of our research. The regulation of FASN gene expression deserves further study. 
Adipocyte fatty acid-binding protein (FABP4), which contributes to efficient fat storage and utilization, has been suggested as a candidate for meat quality traits. FABP4 is a 15$\mathrm{kDa}$ protein involved in the intracellular targeting of fatty acids and metabolic homeostasis. The gene is exclusively expressed in adipocytes and macrophages that infiltrate the tissue bed, and in adipogenic cell lines (Gardan et al., 2007). FABP4 has been proposed to play a critical role in the balance between lipolysis and lipogenesis in adipocytes (Chmurzynska, 2006). As it appears late during adipogenesis (Spiegelman et al., 1983), FABP4 content has recently been suggested as a valuable marker for lipid content and adipocyte number (Zhao et al., 2010). The gene, acting as a key mediator of intracellular transport and metabolism of fatty acids, is expressed in a differentiation-dependent fashion in adipocytes (Amri et al., 1991; Gregoire et al., 1998). The present microarray analysis indicated that FABP4 is involved in fatty acid metabolism, lipid biosynthesis and lipid metabolism. Further polymorphism analysis found a mutation of $\mathrm{C} \rightarrow \mathrm{A}$ in the $5^{\prime}$ regulatory region of the Songliao black swine gene FABP4. We provide evidence that the polymorphism is associated with marbling and IMF content. Evidence from the aforementioned research and the present study led us to hypothesize that FABP4 is a promising candidate gene for improving the quality of pork. Furthermore, research concerning the application of molecular markers in breeding could be of use in the future.

\section{Genes associated with regulation of actin}

Genetic control of skeletal muscle cell and adipocyte in pork is inalienable. The information network of regulatory mechanism between muscle and adipocytes forms the molecular basis of development of muscle and fat-related traits. In order to determine genes related to swine meat quality, it is of great importance to connect muscle to fat. Therefore, it is imperative to study genes associated with the regulation of actin, in addition to genes related to fat metabolism. COFILIN protein (COFILIN) is an actin-binding protein that is ubiquitously expressed in eukaryotic cells, where its basic function is to bind and depolymerize F-actin. In vivo COFILIN activity has been found to be regulated by phosphorylation, dephosphorylation, phosphoinositides, and $\mathrm{pH}$. The COFILIN-mediated intracellular signaling pathway is involved in the reorganization of the actin cytoskeleton and in muscle morphogenesis and regeneration (Marrube et al., 2004). Research has also indicated that COFILIN is coexpressed with smooth muscle actin in the culture-induced conversion of premyofibroblasts to myofibroblasts. COFILIN is a potential marker of myofibroblast differentiation in valve interstitial cell populations and stress fiber assembly, and the formation of stable actin filament arrays in cells is also mediated by COFILIN (Arber et al., 1998). In the present study, COFILIN was involved in positive regulation of actin filament depolymerization, actin filament organization, actin binding, and cortical actin cytoskeleton. Furthermore, COFILIN is involved in the regulation of the actin cytoskeleton and in axon guidance. These results are consistent with earlier findings in fibroblasts (Malmstrom et al., 2004; Clement et al., 2005; Ball et al., 2007). COFILIN therefore appears to be an important gene with influences on meat quality traits and is worthy of further study.

In summary, the present study reports the results of systematic temporal screening of the transcriptome of the longissimus dorsi of Northeastern Indigenous and Large White pigs and through this provides novel insight that should help to more comprehensively elucidate the biological mechanisms underlying variations in pork quality. Moreover, it may identify new targets for meat quality research and form the basis for selective breeding towards improved pork quality. 


\section{ACKNOWLEDGMENTS}

Research was supported by the Tackle Key Problems in Science and Technology Program from Jilin Province (\#09ZDGG008) and the Young Foundation of Scientific Research from the Agronomy Department of Jilin University (\#4305050102E2). The authors thank Shumin Zhang for the maintenance and care of the animals used in this research.

\section{REFERENCES}

Amri EZ, Bertrand B, Ailhaud G and Grimaldi P (1991). Regulation of adipose cell differentiation. I. Fatty acids are inducers of the aP2 gene expression. J. Lipid Res. 32: 1449-1456.

Arber S, Barbayannis FA, Hanser H, Schneider C, et al. (1998). Regulation of actin dynamics through phosphorylation of cofilin by LIM-kinase. Nature 393: 805-809.

Ball SG, Shuttleworth CA and Kielty CM (2007). Platelet-derived growth factor receptor-alpha is a key determinant of smooth muscle alpha-actin filaments in bone marrow-derived mesenchymal stem cells. Int. J. Biochem. Cell Biol. 39: 379-391.

Britton CH, Mackey DW, Esser V, Foster DW, et al. (1997). Fine chromosome mapping of the genes for human liver and muscle carnitine palmitoyltransferase I (CPT1A and CPT1B). Genomics 40: 209-211.

Brouns F and van der Vusse GJ (1998). Utilization of lipids during exercise in human subjects: metabolic and dietary constraints. Br. J. Nutr. 79: 117-128.

Chmurzynska A (2006). The multigene family of fatty acid-binding proteins (FABPs): function, structure and polymorphism. J. Appl. Genet. 47: 39-48.

Clement S, Hinz B, Dugina V, Gabbiani G, et al. (2005). The N-terminal Ac-EEED sequence plays a role in alpha-smoothmuscle actin incorporation into stress fibers. J. Cell Sci. 118: 1395-1404.

Douaire M, Le Fur N, el Khadir-Mounier C, Langlois P, et al. (1992). Identifying genes involved in the variability of genetic fatness in the growing chicken. Poult. Sci. 71: 1911-1920.

Fu Y, Luo N, Klein RL and Garvey WT (2005). Adiponectin promotes adipocyte differentiation, insulin sensitivity, and lipid accumulation. J. Lipid Res. 46: 1369-1379.

Gardan D, Louveau I and Gondret F (2007). Adipocyte- and heart-type fatty acid binding proteins are both expressed in subcutaneous and intramuscular porcine (Sus scrofa) adipocytes. Comp. Biochem. Physiol. B. Biochem. Mol. Biol. 148: $14-19$.

Gregoire FM, Smas CM and Sul HS (1998). Understanding adipocyte differentiation. Physiol. Rev. 78: 783-809.

Hamilton DN, Miller KD, Ellis M, McKeith FK, et al. (2003). Relationships between longissimus glycolytic potential and swine growth performance, carcass traits, and pork quality. J. Anim. Sci. 81: 2206-2212.

Kadowaki T and Yamauchi T (2005). Adiponectin and adiponectin receptors. Endocr. Rev. 26: 439-451.

Kadowaki T, Yamauchi T, Kubota N, Hara K, et al. (2007). Adiponectin and adiponectin receptors in obesity-linked insulin resistance. Novartis Found. Symp. 286: 164-176.

Malmstrom J, Lindberg H, Lindberg C, Bratt C, et al. (2004). Transforming growth factor-beta 1 specifically induce proteins involved in the myofibroblast contractile apparatus. Mol. Cell Proteomics 3: 466-477.

Marrube G, Rozen F, Pinto GB, Pacienza N, et al. (2004). New polymorphism of FASN gene in chicken. J. Appl. Genet. 45: 453-455.

Morris CA, Cullen NG, Glass BC, Hyndman DL, et al. (2007). Fatty acid synthase effects on bovine adipose fat and milk fat. Mamm. Genome 18: 64-74.

Muñoz G, Óvilo C, Noguera JL, Sanchez A, et al. (2003). Assignment of the fatty acid synthase (FASN) gene to pig chromosome 12 by physical and linkage mapping. Anim. Genet. 34: 234-235.

Nowacka-Woszuk J, Szczerbal I, Fijak-Nowak H and Switonski M (2008). Chromosomal localization of 13 candidate genes for human obesity in the pig genome. J. Appl. Genet. 49: 373-377.

Pfaffl MW (2001). A new mathematical model for relative quantification in real-time RT-PCR. Nucleic Acids Res. 29 : e45.

Picard B, Lefaucheur L, Berri C and Duclos MJ (2002). Muscle fibre ontogenesis in farm animal species. Reprod. Nutr. Dev. 42: 415-431.

Ponsuksili S, Murani E, Walz C, Schwerin M, et al. (2007). Pre- and postnatal hepatic gene expression profiles of two pig breeds differing in body composition: insight into pathways of metabolic regulation. Physiol. Genomics 29: 267-279.

Price NT, Jackson VN, van der Leij FR, Cameron JM, et al. (2003). Cloning and expression of the liver and muscle 
isoforms of ovine carnitine palmitoyltransferase 1: residues within the N-terminus of the muscle isoform influence the kinetic properties of the enzyme. Biochem. J. 372: 871-879.

Roy R, Gautier M, Hayes H, Laurent P, et al. (2001). Assignment of the fatty acid synthase (FASN) gene to bovine chromosome 19 (19q22) by in situ hybridization and confirmation by somatic cell hybrid mapping. Cytogenet. Cell Genet. 93: 141-142.

Roy R, Ordovas L, Zaragoza P, Romero A, et al. (2006). Association of polymorphisms in the bovine FASN gene with milk-fat content. Anim. Genet. 37: 215-218.

Sambrook J, Fritsch EF and Maniatis T (1989). Molecular Cloning: A Laboratory Manual. 2nd edn. Cold Spring Harbor Laboratory Press, Woodbury.

Sourdioux M, Brevelet C, Delabrosse Y and Douaire M (1999). Association of fatty acid synthase gene and malic enzyme gene polymorphisms with fatness in turkeys. Poult. Sci. 78: 1651-1657.

Spiegelman BM, Frank M and Green H (1983). Molecular cloning of mRNA from 3T3 adipocytes. Regulation of mRNA content for glycerophosphate dehydrogenase and other differentiation-dependent proteins during adipocyte development. J. Biol. Chem. 258: 10083-10089.

Tichopad A, Dilger M, Schwarz G and Pfaffl MW (2003). Standardized determination of real-time PCR efficiency from a single reaction set-up. Nucleic Acids Res. 31: e122.

van der Leij FR, Takens J, van der Veen AY, Terpstra P, et al. (1997). Localization and intron usage analysis of the human CPT1B gene for muscle type carnitine palmitoyltransferase I. Biochim. Biophys. Acta 1352: 123-128.

van der Leij FR, Cox KB, Jackson VN, Huijkman NC, et al. (2002). Structural and functional genomics of the CPT1B gene for muscle-type carnitine palmitoyltransferase I in mammals. J. Biol. Chem. 277: 26994-27005.

Wang D, Harrison W, Buja LM, Elder FF, et al. (1998). Genomic DNA sequence, promoter expression, and chromosomal mapping of rat muscle carnitine palmitoyltransferase I. Genomics 48: 314-323.

Yamazaki N, Yamanaka Y, Hashimoto Y, Shinohara Y, et al. (1997). Structural features of the gene encoding human muscle type carnitine palmitoyltransferase I. FEBS Lett. 409: 401-406.

Yang YA, Morin PJ, Han WF, Chen T, et al. (2003). Regulation of fatty acid synthase expression in breast cancer by sterol regulatory element binding protein-1c. Exp. Cell Res. 282: 132-137.

Yu GS, Lu YC and Gulick T (1998). Co-regulation of tissue-specific alternative human carnitine palmitoyltransferase Ibeta gene promoters by fatty acid enzyme substrate. J. Biol. Chem. 273: 32901-32909.

Zhao S, Wang J, Song X, Zhang X, et al. (2010). Impact of dietary protein on lipid metabolism-related gene expression in porcine adipose tissue. Nutr. Metab. 7: 6.

Zhao SH, Recknor J, Lunney JK, Nettleton D, et al. (2005). Validation of a first-generation long-oligonucleotide microarray for transcriptional profiling in the pig. Genomics 86: 618-625. 